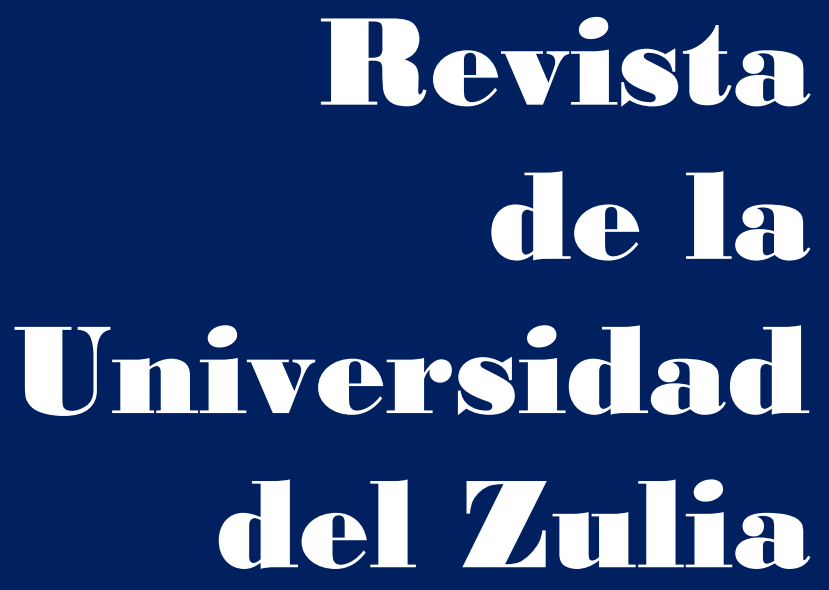

Fundada en 1947

por el Dr. Jesús Enrique Lossada

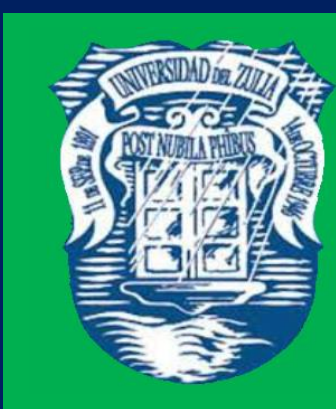

Ciencias del

Agred

Ingemieria

y Teenología
Añต 12 No 32

Enero - Abril 2021

Tercera Época

Maracailbo-Venezuela 


\title{
Possibility of using technogenically polluted floodplain landscapes
}

\author{
A.L. Silaev * \\ E.V.Smolsky ** \\ G.V. Chekin *** \\ V. Yu. Simonov **** \\ A. Novikov *****
}

\begin{abstract}
The article provides a modern assessment of technogenically polluted floodplain landscapes of various rivers of the Polesian Lowland. The carried out ecological monitoring of productivity, radioactivity of perennial grasses and fertility of floodplain soils revealed the following results, tendencies and regularities: the most favorable set of conditions for obtaining an air-dry mass of grasses with the highest productivity up to $5 \mathrm{t} /$ ha was found on the floodplain of the Iput River, possibly used as hayfields floodplain lands at present, with a ${ }^{137} \mathrm{Cs}$ pollution density below $555 \mathrm{kBq}$ $/ \mathrm{m}^{2}$ obtained after the Chernobyl accident, the use of floodplains as hayfields with a ${ }^{137} \mathrm{Cs}$ pollution density above $555 \mathrm{kBq} / \mathrm{m}^{2}$ is impossible, coarse fodder from the floodplains of the Iput and Besed rivers is 6.4 and 6.6 times higher than the permissible level of ${ }^{137} \mathrm{Cs}$ content in products, the content of organic matter, calcium and magnesium grew in the landscape of the floodplain by subsystems: near-river $\rightarrow$ central $\rightarrow$ near-terrace landscape, a high content of mobile phosphorus and exchangeable potassium, respectively, from 227 to 362 and 122 to $266 \mathrm{mg}$ / kg were found in the nearterrace subsystem of the studied floodplains, the effect of fertility on an increase in productivity is positive, with the exception of the effect of acidity and negative on an increase in specific activity ${ }^{137} \mathrm{Cs}$, established an average role $(0.30<\mathrm{r}<0.70)$ of fertility indicators in increasing productivity, the correlation coefficient $(\mathrm{r})$ ranged from 0.41 to 0.64 and -0.38 , revealed a strong role $(\mathrm{r}>0.70)$ of the content of phosphorus available for a plant in a decrease in the specific activity of ${ }^{137} \mathrm{Cs}$ in the airdry mass of grasses, the correlation coefficient (r) was -0.70 .
\end{abstract}

KEY WORDS: radioactive contamination, floodplain meadow, alluvial soil, indicators of soil fertility, specific activity of ${ }^{137} \mathrm{Cs}$, correlation, soil pollution, feed, productivity, radioactivity, soil fertility, correlation.

${ }^{*}$ Candidate of Agricultural Sciences, Associate Professor, Head of the Department of Agrochemistry, Soil Science and Ecology, Bryansk State Agrarian University, 2A, Sovetskaya street. E-mail: kafeap@bgsha.com

${ }^{* *}$ Candidate of Agricultural Sciences, Associate Professor of the Department of Agrochemistry, Soil Science and Ecology, Bryansk State Agrarian University, 2A, Sovetskaya street. E-mail: sev_84@mail.ru

${ }^{* *}$ Candidate of Agricultural Sciences, Associate Professor, Department of Agrochemistry, Soil Science and Ecology, Bryansk State Agrarian University, 2A, Sovetskaya street. E-mail: gb-swamp@yandex.ru

**** Candidate of Agricultural Sciences, Associate Professor of the Department of Agronomy, Breeding and Seed Production, Bryansk State Agrarian University, 2A, Sovetskaya street. E-mail: simonov_84@mail.ru

***** Student Bryansk State Agrarian University, 2A, Sovetskaya street, village of Kokkino, Vygonichsky district, Bryansk region, Russia,243365

Recibido: 27/10/2020

Aceptado: 08/12/2020 


\section{Posibilidad de utilizar llanuras aluviales contaminadas tecnogénicamente}

El artículo ofrece una evaluación de los paisajes de llanuras aluviales contaminadas tecnológicamente, de varios ríos de las tierras bajas de Polesian. El monitoreo ecológico realizado de productividad, radiactividad de gramíneas perennes y fertilidad de suelos de llanura aluvial reveló los siguientes resultados, tendencias y regularidades: el conjunto de condiciones más favorables para obtener una masa de gramíneas secas al aire con la mayor productividad hasta $5 \mathrm{t} /$ ha se encontró en la llanura aluvial del río Iput, posiblemente utilizada como tierras de llanura aluvial de campos de heno en la actualidad, con una densidad de contaminación de 137Cs inferior a $555 \mathrm{kBq} / \mathrm{m} 2$ obtenida después del accidente de Chernobyl, el uso de llanuras de inundación como campos de heno con una densidad de contaminación de 137Cs superior a $555 \mathrm{kBq} / \mathrm{m} 2$ es imposible, el forraje grueso de las llanuras aluviales de los ríos Iput y Besed es 6.4 y 6.6 veces mayor que el nivel permisible de contenido de 137 Cs en los productos, el contenido de materia orgánica, calcio y magnesio creció en el paisaje de la llanura aluvial por subsistemas : paisaje cercano al río $\rightarrow$ central $\rightarrow$ cercano a la terraza, un alto contenido de fósforo móvil y potasio intercambiable, respectivamente, de 227 a 362 a nd se encontraron 122 a $266 \mathrm{mg} / \mathrm{kg}$ en el subsistema de terrazas cercanas de las llanuras de inundación estudiadas, el efecto de la fertilidad sobre el aumento de la productividad es positivo, con excepción del efecto de la acidez y negativo sobre el aumento de la actividad específica 137Cs, establecido un papel promedio $(0,30<\mathrm{r}<0,70)$ de los indicadores de fecundidad en el aumento de la productividad, el coeficiente de correlación (r) osciló entre 0,4l y 0,64 y -0,38, reveló un papel fuerte $(\mathrm{r}>0,70)$ del contenido de fósforo disponible para un planta en una disminución en la actividad específica de 137Cs en la masa seca al aire de gramíneas, el coeficiente de correlación (r) fue de $-0,70$.

PALABRAS CLAVES: contaminación radiactiva, pradera de llanura aluvial, suelo aluvial, indicadores de fertilidad del suelo, actividad específica de 137Cs, correlación, contaminación del suelo, alimentación, productividad, radiactividad, fertilidad del suelo, correlación.

\section{Introduction}

A special place among the various soils belongs to floodplain soils, which have a strong difference from the soils of watershed areas both in their origin and characteristics, as well as in their use in the process of management. Floodplain soils, occupying a relatively small area, are still of significant value for agricultural production. (Balabko, Sneg, Lokalina, et-al 2016; Dobrovol'ski, Balabko, Stasjuk et-al 2011; Oreshkin, Kuzmenkova., Ulyanochkina, et-al 2000).

Floodplain soils in the central regions of the European part of Russia, which are in dire need of the production of dairy products to supply cities and industrial centers 
REVISTA DE LA UNIVERSIDAD DEL ZULIA. 3ª época. Año 12 N 32, 2021

A.L. Silaev et al. // Possibility of using technogenically polluted floodplain landscapes, 102-113

DOI: http://dx.doi.org/10.46925//rdluz.32.08

(Dobrovol'ski,2005) are especially valuable, which is largely complicated by radioactive contamination of a vast territory (Aleksakhin, Sanzharova, Fesenko, 2006; Belous, Prudnikov, Shcheglov,2019; Prosyannikov, Silaev, Koshelev 2000).

The non-chernozem zone of Russia has all the possibilities for the accelerated development of dairy farming: vast land resources, fodder base (Chirkov, Drobyshevskaya, 2016; Prosyannikov, Balabko, Prosyannikov, 2012; Trofimov, Trofimova, Yakovleva, 2010) fodder production acquires particular importance in conditions of radioactive contamination of the territory with artificial long-lived radionuclides, when the development of the region is associated with the return to circulation of agricultural territories removed from agricultural turnover as a result of the Chernobyl precipitation on them (Aleksakhin, 2009; Belous, 2016; Panov, Prudnikov, Titov, et-al 2019; Tsybulko, Panov, Titov, et-al 2020).

The aim of this work is to assess the current state of the use of technologically polluted floodplains as hayfields and to assess the role of fertility in changing the productivity and radioactivity of natural grass stand.

\section{Material and research methods}

The methodological basis for the study was the concept of environmental monitoring, a systematic approach and the scientific provisions of agricultural radiology.

Soil and plant samples were taken within the floodplain landscapes of the Iput, Unecha, Besed rivers located in the Polesian Lowland, technogenically contaminated as a result of the Chernobyl accident, in 2019 after 33 years after the accident, to determine the current state of soil fertility and the suitability of floodplain landscapes in meadow growing.

The territory of the floodplain, depending on its distance from the riverbed, is divided into 3 subsystems: near-river, central and near-terrace. They differ in the composition of alluvial deposits, relief, hydrology and, as a consequence, in vegetation and soil cover (Fig. 1).

Organic matter, exchangeable acidity, the content of mobile phosphorus and exchangeable potassium, calcium and magnesium in soil samples were determined at the center for collective use of scientific equipment at the Bryansk State Agrarian University according to generally accepted methods. 
REVISTA DE LA UNIVERSIDAD DEL ZULIA. 3época. Año 12 N 32, 2021

A.L. Silaev et al. // Possibility of using technogenically polluted floodplain landscapes, 102-113

DOI: http://dx.doi.org/10.46925//rdluz.32.08

Alluvial
TWS.
Atmospheric TWS

Floodplain

near river

central
Slope TWS

near - terrace

Ground pressure TWS

River

Waterproofing

\section{Legend:}

Floodplain ecological subsystems: TWS - type of water supply. River water level or flood: a - flood; b dry season on average for precipitation in a year; $\mathrm{c}$ - dry season in a dry year.

Fig. 1- Profile of a typical floodplain landscape

The soils of the study areas and data on technogenic pollution with ${ }^{137} \mathrm{Cs}$ are presented in Table 1.

Table-1: Objects of research and their technogenic pollution

\begin{tabular}{|c|c|c|}
\hline Floodplain & $\begin{array}{c}\text { Density of }{ }^{137} \mathrm{Cs} \\
\text { contamination in the } \\
\text { territory after the } \\
\text { Chernobyl accident, kBq / } \\
\mathrm{m}^{2}\end{array}$ & The soil \\
\hline \multirow{3}{*}{$\begin{array}{l}\text { Unecha } \\
\text { River }\end{array}$} & \multirow{3}{*}{$185-555$} & $\begin{array}{l}\text { Alluvial soddy acidic layered primitive shortened } \\
\text { sandy loam }\end{array}$ \\
\hline & & $\begin{array}{l}\text { Alluvial meadow acidic shallow shortened light } \\
\text { loamy }\end{array}$ \\
\hline & & Alluvial humus-boggy medium loamy \\
\hline \multirow{3}{*}{ Iput River } & \multirow{3}{*}{$555-1480$} & $\begin{array}{l}\text { Alluvial soddy acidic layered primitive shortened } \\
\text { sandy loam }\end{array}$ \\
\hline & & $\begin{array}{l}\text { Alluvial meadow acidic shallow shortened light } \\
\text { loamy }\end{array}$ \\
\hline & & Alluvial humus-boggy medium loamy \\
\hline \multirow{3}{*}{$\begin{array}{l}\text { Besed } \\
\text { River }\end{array}$} & \multirow{3}{*}{ over 1480} & $\begin{array}{l}\text { Alluvial soddy acidic layered primitive shortened } \\
\text { sandy loam }\end{array}$ \\
\hline & & $\begin{array}{l}\text { Alluvial meadow acidic shallow shortened light } \\
\text { loamy }\end{array}$ \\
\hline & & Alluvial humus-boggy medium loamy \\
\hline
\end{tabular}


REVISTA DE LA UNIVERSIDAD DEL ZULIA. 3ª época. Año $12 \mathrm{~N}^{\circ} 32,2021$

A.L. Silaev et al. // Possibility of using technogenically polluted floodplain landscapes, 102-113

DOI: http://dx.doi.org/10.46925//rdluz.32.08

Geobotanical survey of herbage of floodplain ecosystems was carried out according to the generally accepted method (Table 2). To determine the productivity, a $0.25 \mathrm{~m}^{2}$ frame was used, placed on four counting sites, the plant mass from each counting site was dried to standard moisture content (17\%), and the yield of the air-dry grass mass was calculated. Plants were sorted out according to economic characteristics: dominants used in meadow growing, codominants - forbs, are not of economic value.

The specific activity of ${ }^{137} \mathrm{Cs}$ in the air-dry mass of grasses was determined at USK "Gamma Plus" (Russia); the measurement error did not exceed 10\%.

Correlation analysis of productivity and specific activity of ${ }^{137} \mathrm{Cs}$ of air-dry matter of grasses and indicators of soil fertility was carried out; the number of pairs in the analysis was 9.

Table-2: Agrobotanical composition of herbage of floodplain landscapes

\begin{tabular}{|c|c|c|}
\hline $\begin{array}{c}\text { Floodplain } \\
\text { subsystem }\end{array}$ & Dominant & Sodominant \\
\hline near-river & $\begin{array}{c}\text { Alopecurus pratensis } \\
\text { Bromopsis inermis }\end{array}$ & $\begin{array}{c}\text { Rumex thyrsiflorus } \\
\text { Achillea millefolium } \\
\text { Plantago media } \\
\text { Ranunculus acris }\end{array}$ \\
\hline central & $\begin{array}{c}\text { Digraphis arundinacea } \\
\text { Glyceria aquatica }\end{array}$ & $\begin{array}{c}\text { Eqvisetum arvense } \\
\text { Filipendula ulmaria }\end{array}$ \\
\hline near-terrace & $\begin{array}{c}\text { Carex vulpina } \\
\text { Carex vesicaria } \\
\text { Carex acuta }\end{array}$ & $\begin{array}{c}\text { Eqvisetum arvense } \\
\text { Lythrum salicaria }\end{array}$ \\
\hline
\end{tabular}

2. Research results and their discussion

The climatic conditions of the Polesian Lowland and the natural fertility of the soils of the floodplain, to varying degrees, ensure the productivity of the floodplain landscape. The most favorable set of conditions developed on the Iput River floodplain, where the total productivity of the floodplain landscape was $5.07 \mathrm{t} / \mathrm{h}$ of air-dry grass biomass, which is 1.8 times more than in the floodplains of the Unecha and Besed rivers (Table 3). 
REVISTA DE LA UNIVERSIDAD DEL ZULIA. 3ª época. Año $12 \mathrm{~N}^{\circ} 32,2021$

A.L. Silaev et al. // Possibility of using technogenically polluted floodplain landscapes, 102-113

DOI: http://dx.doi.org/10.46925//rdluz.32.08

Table-3: Productivity and specific activity of ${ }^{137} \mathrm{Cs}$ of air-dry mass of grasses in floodplain meadows

\begin{tabular}{|c|c|c|c|c|c|c|}
\hline \multirow{2}{*}{ Group of plants } & \multicolumn{7}{|c|}{\begin{tabular}{c} 
Floodplain landscape \\
\cline { 2 - 6 }
\end{tabular}} & $\begin{array}{c}\text { near-river } \\
\text { subsystem }\end{array}$ & $\begin{array}{c}\text { central } \\
\text { subsystem }\end{array}$ & $\begin{array}{c}\text { near-terrace } \\
\text { subsystem }\end{array}$ \\
\cline { 2 - 7 } & $\mathrm{P}$ & SA & $\mathrm{P}$ & SA & P & SA \\
\hline \multicolumn{7}{|c|}{ floodplain of the Unecha River } \\
\hline dominants & 0,26 & 33,2 & 0,34 & 55,1 & 0,78 & 258,0 \\
\hline codominants & 0,43 & 50,4 & 0,44 & 71,9 & 0,60 & 135,4 \\
\hline sum / average & 0,69 & 41,8 & 0,78 & 63,5 & 1,38 & 196,7 \\
\hline \multicolumn{7}{|c|}{ floodplain of the Iput River } \\
\hline dominants & 0,46 & 2045,0 & 1,63 & 2054,0 & 1,38 & 878,0 \\
\hline codominants & 0,17 & 1278,0 & 0,41 & 1145,0 & 1,02 & 228,2 \\
\hline sum / average & 0,63 & 1661,5 & 2,04 & 1599,5 & 2,40 & 553,1 \\
\hline \multicolumn{7}{|c|}{ floodplain of the Besed River } \\
\hline dominants & 0,44 & 290,9 & 0,39 & 1180,0 & 1,12 & 54,1 \\
\hline codominants & 0,31 & 290,9 & 0,24 & 2099,0 & 0,31 & 56,6 \\
\hline sum / average & 0,75 & 290,9 & 0,63 & 1639,5 & 1,43 & 55,4 \\
\hline
\end{tabular}

Note: $\mathrm{P}$ - productivity, $\mathrm{t} / \mathrm{ha}, \mathrm{SA}$ - specific activity of ${ }^{137} \mathrm{C}, \mathrm{Bq} / \mathrm{kg}$

The predominance of an economically valuable group of plants in the central subsystem of the floodplain of the Iput River, the place of the main meadow forage production, was established. The productivity of dominants is 3.9 times higher than that of forbs. Forbs prevailed in the central subsystem of the Unecha River floodplain, and the productivity of economically valuable grasses in the Besed River floodplain was 1.6 times higher than the biomass of forbs. Probably, such productivity of economically valuable grasses in the central part of the floodplain of the Iput River is associated with the peculiarities of this floodplain and human economic activity leading to its cultivation.

The productivity of the floodplain of the Iput River was at the levels of productivity of the floodplain of the Desna River in its middle course located in the Dnieper lowland (Prosyannikov, Balabko, Prosyannikov, 2011)

The central floodplains of the Unecha and Besed rivers, apparently, are little used in the production of forage; therefore, forbs either predominates over economically valuable plants, or were at the same level. 


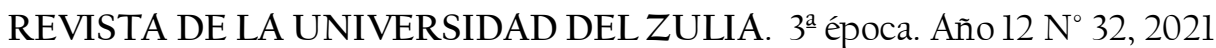

A.L. Silaev et al. // Possibility of using technogenically polluted floodplain landscapes, 102-113

DOI: http://dx.doi.org/10.46925//rdluz.32.08

As a result of the Chernobyl accident, the sections of the study area, according to the density of radioactive contamination with ${ }^{137} \mathrm{Cs}$, were arranged in the following order: the floodplain of the Unecha River - $185-555 \mathrm{kBq} / \mathrm{m}^{2}$, the floodplain of the Iput River - 555-1480 $\mathrm{kBq} / \mathrm{m}^{2}$, the floodplain of the Besed River - over $1480 \mathrm{kBq} / \mathrm{m}^{2}$ (Sychev, Lunev, Orlov, et-al 2016).

According to the technical regulations of the Customs Union "On the safety of feed and feed additives" (TR 201_/ 00_/ TC), at present the content of radionuclides in the airdry mass of grasses (hay) should not exceed $250 \mathrm{~Bq} / \mathrm{kg}$. After 33 years since the fallout of radioactive fallout, the main dose-forming component of which was ${ }^{137} \mathrm{Cs}$, the climatic conditions of the Polesian Lowland and the natural fertility of the floodplain soils of the Iput and Besedi rivers do not allow obtaining roughage with an acceptable content of ${ }^{137} \mathrm{Cs}$ in products, without the use of protective measures, the excess in the central subsystem of the floodplain by 6.4 and 6.6 times, respectively (Table 3). It was established that after 33 years after the accident, it is possible to use floodplain lands with a ${ }^{137} \mathrm{C}$ s contamination density of $185-555 \mathrm{kBq} / \mathrm{m}^{2}$ as hayfields without the use of any rehabilitation measures. The use of the central floodplains of the Iput and Besed rivers, even after 33 years after the Chernobyl accident, is unacceptable without the use of protective measures to prevent the transfer of radionuclide from soil to plants.

In the Polesian Lowland, the use of river floodplains with a ${ }^{137} \mathrm{Cs}$ contamination density of the territory over $555 \mathrm{kBq} / \mathrm{m}^{2}$ after the Chernobyl accident in fodder production is unacceptable without special measures for the rehabilitation of these lands (Belous, Smolsky, Chesalin, et-al 2016; Pakshina, Shapovalov, Chesalin, et-al 2019; Panov, Aleksakhin, Muzalevskaya, et-al 2009)

Climatic conditions of the Polesian Lowland, vegetation, hydrology, geomorphology, lithology of the territory form indicators of the fertility of floodplain soils (Table 4).

The following regularities of fertility indicators were established: the organic matter of the soils of the floodplains of the Unecha, Iput, and Besed rivers increased from the riverbed to the near-terrace subsystem, respectively, by 7.0, 2.7, and 13.4 times, which is associated with the distribution of alluvium and the hydrological and geomorphological conditions of the site; similar trends as with a change in organic matter were observed with a change in the content of calcium and magnesium. 


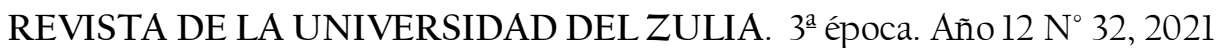

A.L. Silaev et al. // Possibility of using technogenically polluted floodplain landscapes, 102-113

DOI: http://dx.doi.org/10.46925//rdluz.32.08

Table-4: Indicators of soil fertility of floodplains

\begin{tabular}{|c|c|c|c|c|c|c|}
\hline \multirow[t]{2}{*}{ The soil } & $\begin{array}{l}\text { Organic } \\
\text { matter }\end{array}$ & $\mathrm{pH}_{\mathrm{KCl}}$ & $\mathrm{P}_{2} \mathrm{O}_{5}$ & $\mathrm{~K}_{2} \mathrm{O}$ & $\mathrm{Ca}$ & $\mathrm{Mg}$ \\
\hline & $\%$ & units & \multicolumn{2}{|c|}{$\mathrm{mg} / \mathrm{kg}$} & \multicolumn{2}{|c|}{$\mathrm{mmol} / \mathrm{l} 00 \mathrm{~g}$} \\
\hline \multicolumn{7}{|c|}{ floodplain of the Unecha River } \\
\hline $\begin{array}{r}\text { Alluvial soddy acidic layered primitive } \\
\text { shortened sandy loam }\end{array}$ & 1,98 & 5,26 & 310 & 54 & 5,47 & 1,16 \\
\hline $\begin{array}{r}\text { Alluvial meadow acidic shallow shortened } \\
\text { light loamy }\end{array}$ & 3,15 & 4,52 & 241 & 73 & 9,72 & 1,66 \\
\hline Alluvial humus-boggy medium loamy & 13,83 & 4,50 & 362 & 156 & $\begin{array}{c}22,4 \\
7\end{array}$ & 2,22 \\
\hline \multicolumn{7}{|c|}{ floodplain of the Iput River } \\
\hline $\begin{array}{r}\text { Alluvial soddy acidic layered primitive } \\
\text { shortened sandy loam }\end{array}$ & 3,93 & 4,12 & 57 & 102 & 5,82 & 1,10 \\
\hline $\begin{array}{l}\text { Alluvial meadow acidic shallow } \\
\text { shortened medium loamy }\end{array}$ & 7,15 & 4,13 & 116 & 140 & 12,32 & 1,35 \\
\hline Alluvial humus-boggy heavy loamy & 10,67 & 4,36 & 339 & 122 & 19,12 & 2,06 \\
\hline \multicolumn{7}{|c|}{ floodplain of the Besed River } \\
\hline $\begin{array}{r}\text { Alluvial soddy acidic layered primitive } \\
\text { shortened sandy loam }\end{array}$ & 1,23 & 4,67 & 83 & 75 & 3,53 & 1,03 \\
\hline $\begin{array}{r}\text { Alluvial soddy acidic low-power } \\
\text { shortened heavy loamy }\end{array}$ & 1,89 & 4,39 & 77 & 39 & 12,03 & 1,26 \\
\hline Alluvial humus-boggy heavy loamy & 16,48 & 4,45 & 227 & 266 & $\begin{array}{c}22,7 \\
6\end{array}$ & 2,97 \\
\hline
\end{tabular}

The conditions of the Polissya lowland determine the acidic reaction of the soil solution, which varies depending on the location of floodplains and soils in the range from 4.12 to 5.26 units.

A high content of mobile phosphorus was revealed, regardless of river floodplains, in the near-terrace part, which varied from 227 to $362 \mathrm{mg} / \mathrm{kg}$. A high content in the floodplain of the Unecha River was also found in other parts of the floodplain, which is apparently due to the presence of sedimentary rocks with a high concentration of phosphorus. Lower values of 57 to $116 \mathrm{mg} / \mathrm{kg}$ were observed for the near-channel and central subsystems of the floodplains of the Iput and Besed rivers.

A similar tendency was found for a high content of exchangeable potassium regardless of river floodplains, in the near-terrace part, which varied from 122 to $266 \mathrm{mg} / \mathrm{kg}$, a high content in the Iput River floodplain was also found in other parts of the floodplain, which is apparently due to the use of potassium use of radioactively contaminated forage lands. Lower 


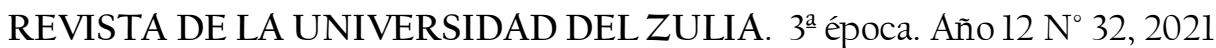

A.L. Silaev et al. // Possibility of using technogenically polluted floodplain landscapes, 102-113

DOI: http://dx.doi.org/10.46925//rdluz.32.08

values of 39 to $79 \mathrm{mg} / \mathrm{kg}$ were observed in the near-channel and central subsystems of the floodplains of the Unecha and Besed rivers.

Having carried out a correlation analysis of the productivity of floodplains and the specific activity of ${ }^{137} \mathrm{Cs}$ of air-dry matter of grasses and indicators of soil fertility (Table 5), it was found that the correlation coefficients of the influence of fertility indicators on productivity are positive, except for exchangeable acidity, and negative when correlated with the specific activity of ${ }^{137} \mathrm{Cs}$. With an increase in soil fertility, the productivity of the floodplain ecosystem increases and the content of ${ }^{137} \mathrm{Cs}$ in the products obtained from floodplain meadows decreases (Aleksakhin, Filipas, Ulyanenko, et-al 2007; Belous, Vorobieva, Belous, et-al 2012; Podolyak, Timofeev, Grebenshchikova, et-al 2005).

Table 5 - Coefficients of correlation of productivity, specific activity of ${ }^{137} \mathrm{Cs}$ and air-dry matter of grasses and indicators of soil fertility

\begin{tabular}{|l|c|c|}
\hline \multicolumn{1}{|c|}{ Soil fertility indicator } & Productivity, $\mathrm{t} / \mathrm{ha}$ & $\begin{array}{c}\text { Specific activity of }{ }^{137} \mathrm{Cs}, \\
\mathrm{Bq} / \mathrm{kg}\end{array}$ \\
\hline Organic matter, $\%$ & 0,64 & $-0,29$ \\
\hline $\mathrm{pH}_{\mathrm{KC}}, \mathrm{units}$ & $-0,38$ & $-0,67$ \\
\hline $\mathrm{P}_{2} \mathrm{O}_{5}, \mathrm{mg} / \mathrm{kg}$ & 0,41 & $-0,70$ \\
\hline $\mathrm{K}_{2} \mathrm{O}, \mathrm{mg} / \mathrm{kg}$ & 0,52 & $-0,24$ \\
\hline $\mathrm{Ca}, \mathrm{mmol} / \mathrm{l00} \mathrm{g}$ soil & 0,64 & $-0,22$ \\
\hline $\mathrm{Mg}, \mathrm{mmol} / \mathrm{l00} \mathrm{g}$ soil & 0,49 & $-0,47$ \\
\hline
\end{tabular}

An average role $(0.30<\mathrm{r}<0.70)$ of fertility indicators in increasing productivity was revealed, the correlation coefficient (r) ranged from 0.41 to 0.64 and -0.38 , which means that with an increase in the content of organic matter and available to plants phosphorus, potassium, calcium and magnesium, and with a decrease in exchangeable acidity, the productivity of floodplain herbage increases. The largest coefficient $(r=0.64)$ of the dependence of indicators was found for organic matter and calcium content.

We revealed a weak role $(r<0.30)$ of organic matter, the content of potassium and calcium available for a plant in a decrease in the specific activity of ${ }^{137} \mathrm{Cs}$ in the air-dry mass of herbs. The correlation coefficient ( $\mathrm{r}$ ) ranges from -0.22 to -0.29 , the average role $(0.30<\mathrm{r}<$ 0.70) of the content of magnesium available for the plant and acidity in the decrease in the specific activity of ${ }^{137} \mathrm{Cs}$ in the air-dry mass of grasses, the correlation coefficient ( $\mathrm{r}$ ) ranged from -0.47 to -0.67 and a strong role $(r>0.70)$ of the content of phosphorus available for the 
REVISTA DE LA UNIVERSIDAD DEL ZULIA. 3ª época. Año 12 N 32, 2021

A.L. Silaev et al. // Possibility of using technogenically polluted floodplain landscapes, 102-113

DOI: http://dx.doi.org/10.46925//rdluz.32.08

plant in the decrease in the specific activity of ${ }^{137} \mathrm{Cs}$ in the air-dry mass of grasses, the correlation coefficient (r) was is equal to -0.70 .

\section{Conclusion}

The carried out ecological monitoring of the current state of technogenically polluted floodplain lands of the Polesian Lowland revealed the following results, tendencies and patterns:

- the most favorable set of conditions for obtaining an air-dry mass of grasses of the highest productivity up to $5 \mathrm{t} /$ ha was found on the floodplain of the Iput River;

- $\quad$ it is possible to use floodplains as hayfields, with a ${ }^{137} \mathrm{Cs}$ pollution density below $555 \mathrm{kBq}$ $/ \mathrm{m}^{2}$ obtained after the Chernobyl accident, the use of floodplains as hayfields with a ${ }^{137} \mathrm{Cs}$ pollution density above $555 \mathrm{kBq} / \mathrm{m}^{2}$ is impossible, coarse fodder from the floodplains of the Iput and Besed rivers, respectively 6.4 and 6.6 times the permissible level of ${ }^{137} \mathrm{Cs}$ content in products;

- the content of organic matter, calcium and magnesium grew in the ecosystem of the floodplain by subsystems: near-channel $\rightarrow$ central $\rightarrow$ near-terrace;

- a high content of mobile phosphorus and exchangeable potassium, respectively, from 227 to 362 and 122 to $266 \mathrm{mg} / \mathrm{kg}$ was found in the near-terrace subsystem of the studied floodplains;

- the effect of fertility on an increase in productivity is positive, with the exception of the effect of acidity, and negative on an increase in the specific activity of ${ }^{137} \mathrm{Cs}$;

- established the average role $(0.30<\mathrm{r}<0.70)$ of fertility indicators in increasing productivity, the correlation coefficient (r) ranged from 0.41 to 0.64 and -0.38 ;

- $\quad$ revealed a strong role $(\mathrm{r}>0.70)$ of the content of phosphorus available for a plant in a decrease in the specific activity of ${ }^{137} \mathrm{Cs}$ in the air-dry mass of grasses, the correlation coefficient (r) was -0.70 .

Conflict of Interest: absent Source of Funding: absent 
REVISTA DE LA UNIVERSIDAD DEL ZULIA. $3^{a}$ época. Año $12 \mathrm{~N}^{\circ}$ 32, 2021

A.L. Silaev et al. // Possibility of using technogenically polluted floodplain landscapes, 102-113

DOI: http://dx.doi.org/10.46925//rdluz.32.08

\section{References}

Aleksakhin R.M. (2009). Radioactive contamination as a type of soil degradation. Eurasian Soil Science. Vol. 42. No. 12. Pp. 1386-1396.

Aleksakhin R.M., Filipas A.S., Ulyanenko L.N., Zhigareva T.L., Anisimov V.S. (2007). On the problem of farming under conditions of technogenic impact on agricultural landscapes. Bulletin of the Russian Academy of Agricultural Sciences. No 3. Pp. 26-28.

Aleksakhin R.M., Sanzharova N.I., Fesenko S.V. (2006). Radioecology and the accident at the Chernobyl nuclear power plant. Atomic Energy. Vol. 100. No 4. Pp. 257-263.

Balabko P.N., Sneg A.A., Lokalina T.V., Shchedrin V.N. (2016). Soils of the reclaimed floodplain of the upper reaches of the Oka River, used in intensive farming. Scientific journal of the Russian Research Institute of Melioration Problems. No 3 (23). Pp. 116-137.

Belous N.M. (2016). Chernobyl affairs. Bulletin of the Bryansk State Agricultural Academy. No 2 (54). Pp. 3-8.

Belous N.M., Prudnikov P.V., Shcheglov A.M., Smolsky E.V., Belous I.N., Silaev A.L. (2019). Probability of obtaining milk and feed that do not meet the permissible levels of ${ }^{137} \mathrm{Cs}$ in the south-west of the Bryansk region in the distant period after the accident at the Chernobyl nuclear power plant. Radiation and risk. Vol. 28. No. 3. Pp. 36-46.

Belous N.M., Smolsky E.V., Chesalin S.F., Shapovalov V.F. (2016). The role of mineral potassium in reducing the intake of ${ }^{137} \mathrm{Cs}$ in forage grasses and increasing their productivity on radioactively contaminated lands. Agricultural biology. Vol. 51. No 4. Pp. 543-552.

Belous N.M., Vorobieva L.A., Belous I.N. (2012). Optimal parameters of soil fertility for the production of normatively clean agricultural products in the territories contaminated with radionuclides: monograph. Bryansk: Publishing House of the Belarusian State Agricultural Academy, $92 \mathrm{p}$.

Chirkov E.P., Drobyshevskaya T.V. (2016). The role of grassland farming in the reproduction of the forage base. Bulletin of the Bryansk State Agricultural Academy. No 5 (57). Pp. 21-32.

Dobrovol'ski G.V. (2005). Soils of river floodplains in the center of the Russian plain: 2nd edition. Moscow: Moscow State University, 289 p.

Dobrovol'ski G.V., Balabko P.N., Stasjuk N.V., Bykova E.P. 201l. Alluvial soils of river floodplains and deltas and their zonal differences. Arid Ecosystems. Vol. 1. No 3. Pp. 119-124.

Oreshkin V.N., Kuzmenkova V.S., Ulyanochkina T.I., Balabko P.N. (2000). Lead in ironmanganese concretions of varying size from alluvial soils and deposits. Geochemistry International. 2000. Vol. 38. No 6. Pp. 619-623. 
REVISTA DE LA UNIVERSIDAD DEL ZULIA. 3ª época. Año $12 \mathrm{~N}^{\circ} 32,2021$

A.L. Silaev et al. // Possibility of using technogenically polluted floodplain landscapes, 102-113

DOI: http://dx.doi.org/10.46925//rdluz.32.08

Pakshina S.M., Shapovalov V.F., Chesalin S.F., Smolsky E.V., Korenev V.B. (2019). Bio-removal of ${ }^{137} \mathrm{Cs}$ from soil by perennial bluegrass grasses in connection with mineral nutrition and the availability of soil moisture. Agricultural biology. Vol. 54. No 4. Pp. 832-841.

Panov A.V., Aleksakhin R.M., Muzalevskaya A.A., Prudnikov P.V., Novikov A.A. 2009. Influence of rehabilitation measures on ${ }^{137} \mathrm{C}$ s uptake by crops from soils contaminated during the Chernobyl NPP accident. Eurasian Soil Science. Vol. 42. No 4. Pp. 445-457.

Panov A.V., Prudnikov P.V., Titov I.E., Krechetnikov V.V., Ratnikov A.N., Shubina O.A. (2019). Radioecological assessment of agricultural lands and products of the south-western regions of the Bryansk region contaminated with radionuclides as a result of the accident at the Chernobyl nuclear power plant. Radiation hygiene. Vol. 12. No 1. Pp. 25-35.

Podolyak L.G., Timofeev S.F., Grebenshchikova N.V., Arastovich T.V., Zhdanovich V. (2005). Predicting the accumulation of ${ }^{137} \mathrm{Cs}$ and ${ }^{90} \mathrm{Sr}$ in herbage of the main types of meadows of the Belarusian Polesie by agrochemical properties of soil. Radiation biology. Radioecology. Vol. 45. No 1. Pp. 100-111.

Prosyannikov D.E., Balabko P.N., Prosyannikov E.V., Chekin G.V. (2011). Assessment of herbage ecosystems of the Middle Desna floodplain. Problems of Agrochemistry and Ecology. No 2. Pp. 23-28.

Prosyannikov D.E., Balabko P.N., Prosyannikov E.V., Chekin G.V. (2012). The current state of the ecosystem of the right-bank floodplain of the Middle Desna and the prospects for its rational use. Agrochemical Bulletin. No 5. Pp. 9-13.

Prosyannikov E.V., Silaev A.L., Koshelev I.A. (2000). Specific ecological features of ${ }^{137} \mathrm{Cs}$ behavior in river floodplains. Russian Journal of Ecology. Vol.31. No 2. Pp. 132-135.

Sychev V.G., Lunev V.I., Orlov P.M., Belous N.M. (2016). Chernobyl: radiation monitoring of agricultural land and agrochemical aspects of reducing the consequences of radioactive soil contamination (to the 30th anniversary of the man-made accident at the Chernobyl nuclear power plant). Moscow: VNIIA, 184 p.

Trofimov I.A., Trofimova L.S., Yakovleva E.P. (2010). Herbal ecosystems in Russian agriculture. Use and protection of natural resources in Russia. No 4. Pp. 37-40.

Tsybulko N.N., Panov A.V., Titov I.E., Krechetnikov V.V. (2020). Soil and radioecological zoning of radioactively contaminated agricultural lands in Belarus and Russia. Radiation and risk. Bulletin of the National Radiation and Epidemiological Register. Vol. 29. No 2. Pp. 115127. 